
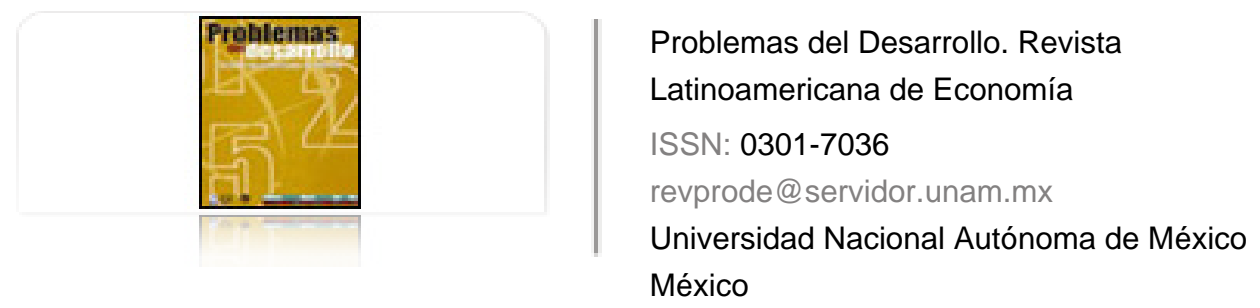

Yasuhara, Tsuyoshi

Manufacturing sector performance in Mexico, under balance of payments-constrained growth Problemas del Desarrollo. Revista Latinoamericana de Economía, vol. 39, núm. 152, enero-marzo, 2008, pp. 29-46

Universidad Nacional Autónoma de México

Distrito Federal, México

Disponible en: http://www.redalyc.org/articulo.oa?id=11820668003

- Cómo citar el artículo

- Número completo

- Más información del artículo

Página de la revista en redalyc.org

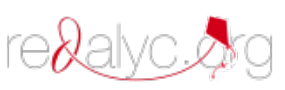

Sistema de Información Científica

Red de Revistas Científicas de América Latina, el Caribe, España y Portugal Proyecto académico sin fines de lucro, desarrollado bajo la iniciativa de acceso abierto 


\title{
MANUFACTURING SECTOR PERFORMANCE IN MEXICO, UNDER BALANCE OF PAYMENTS-CONSTRAINED GROWTH
}

\author{
Tsuyoshi Yasuhara* \\ Fecha de recepción: 28 de agosto de 2007. Fecha de aceptación: 10 de diciembre de 2007.
}

\begin{abstract}
Between 1998 and 2006, the balance of payments-constrained capital productivity for maquiladoras increased significantly, while the same estimated for non-maquiladoras grew only slightly. The two sectors have not built forward and backward linkages, even though they have been constrained similarly by the foreign exchange gap. Trade liberalization policy, particularly the promotion of temporary imports for re-export, has not helped to bring about export-led growth in Mexico.

Key terms: trade liberalization, balance of payments-constrained capital productivity, maquiladora, forward and backward linkage, temporary imports for re-export.
\end{abstract}

* Associate Professor in Economics in the Faculty of Foreign Studies at Nanzan University, Japan (e-mail: tyahara@attglobal.net)

This paper is financially supported by the 2006 Pache I-A-2 Research Subsidy from Nanzan University. 
TSUYOSHI YASUHARA

\section{0}

\section{Resumen}

Entre 1998 y 2006 se estima una gran baja en la productividad del capital restringida por la balanza de pagos de la industria maquiladora, mientras que la no maquiladora decreció ligeramente. Las dos no han establecido la cadena del valor agregado de las actividades productivas; sin embargo la productividad de ambas está restringida por la reserva de divisas. La liberalización comercial, particularmente la promoción de la importación temporal para la reexportación, no ha contribuido al crecimiento dirigido por la exportación de México.

Palabras claves: liberalización comercial, productividad de capital restringida por la balanza de pagos, maquiladora, cadena del valor agregado de las actividades productivas, importación temporal para la reexportación

\section{Résumé}

Entre 1998 et 2006, on observe une grande baisse de la productivité du capital limitée par la balance des paiements de l'industrie de sous-traitance, alors que pour l'industrie non sous-traitante elle a légèrement diminué. Ces deux types d'industrie n'ont pas établi entre elles la chaîne de la valeur ajoutée des activités productives, cependant la productivité de l'industrie sous-traitante et celle des deux est limitée par la réserve de devises. La libéralisation commerciale, notamment la promotion de l'importation temporaire pour la réexportation, n'ont pas contribué à la croissance, laquelle dépend de l'exportation mexicaine.

Mots clés: libéralisation commerciale, productivité du capital limitée par la balance des paiements, sous-traitance, chaîne de la valeur ajoutée des activités productives, importation temporaire pour la réexportation.

\section{Resumo}

Entre 1998 e 2006 estima-se um grande declínio na produtividade do capital restringido pela balança de pagamentos da indústria "maquiladora", enquanto que a não- "maquiladora" decresceu ligeiramente. As duas não estabeleceram a cadeia de valor agregado das atividades produtivas entre elas, no entanto a produtividade da "maquiladora" e a de ambas está restringida pela reserva de divisas. A liberalização comercial, particularmente a promoção da importação temporal para a reexportação, não contribuiu para o crescimento dirigido pela exportação do México.

Palavras-chave: liberalização comercial, produtividade de capital restringida pela balança de pagamentos, "maquiladora", cadeia de valor agregado das atividades produtivas, importação temporal para a reexportação.

\section{Desaarrollo}




\section{Introduction}

N

eoliberal policy is based on the argument that wholesale trade liberalization promotes manufacturing sector exports, which necessarily induce higher levels of productivity and social welfare. Since the North American Free Trade Agreement (NAFTA) came into effect, increased exports from Mexico's representative manufacturing industries have come to be accepted as the engine of development. Meanwhile, some empirical studies support the view that export-led growth policies do not yield high growth rates, but have led to the destruction of major industries ${ }^{1}$. The balance of payments-constrained growth theory, advanced by A. P. Thirlwall, offers a theoretical basis for the interrelations between trade liberalization and deindustrialization.

This paper proposes using an alternative approach to the balance-ofpayments-constrained growth model, one that examines the constraints of the foreign exchange gap on capital productivity. The first part analyzes trade balance performance and the mechanism of temporary import for re-export. The second presents studies of the balance-of-payments-constrained growth model for income and capital productivity. In the third section, we test the empirical study of elasticity between certain factors, to identify the balance-of-payments-constrained growth rates of income and capital productivity in both the maquiladora and the non- maquiladora sectors.

\section{Balance of payment structure and the situation in the manufacturing sector}

The total export of goods, as a share of GDP, increased from 14.5 percent in 1994 to 29.8 percent in 1998. Export growth is attributed to the upward trend of demand in the United States, and the facilitated access to the U.S. market. On average, tariffs on total exports to the United States were cut from 2 percent in 1993 to less than 0.4 percent in $1999 .{ }^{2}$ At the same time, the manufacturing sector accounted for a 4.8 percent growth rate between 1988 and 2000. Nevertheless, that sector has constantly achieved large trade deficits. The manufacturing trade deficit expanded from 14 percent of GDP in 1988 to more than 30 percent in $1994 .^{3}$

See Pieper, 1998, and Shafaeddin, 2005.

Moreno-Brid, Juan Carlos, Jesús Santamaría and Juan Carlos Rivas Valdivia, 2005.

Banco de México Indicadores económicos y financieros, http://www.banxico.org.mx/ eInfo Financiera/FSinfoFinanciera.html 
Figure 1 shows a structural change in Mexico reflected in the trade balance. The evolution of the trade balance as a share of GDP was subject to downward fluctuations during 1987-1993 and 1996-1998, following the periods of trade surplus after the devaluations in 1983-85 and 1995, respectively. The trade balance corresponded to the macroeconomic adjustment phase until 1998. Otherwise, since 1998, fluctuations in the proportion of trade deficits to GDP have stabilized. Since that year, the domestic economy has stagnated, and this has yielded the trade balance results shown below.

Figure 1

Trade balance as a share of GDP and the real exchange rate index (1990 base)

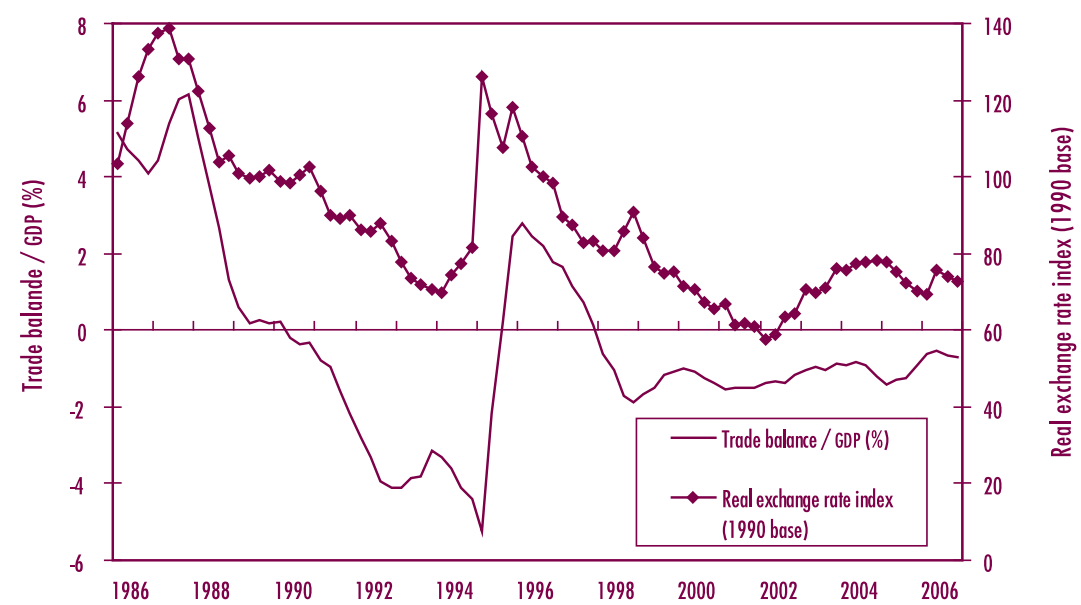

Source: Banco de México Indicadores económicos y financieros,

http://www.banxico. org.mx/eInfo Financiera/FSinfoFinanciera.html

The evolution of trade, shown in Figure 2, supports the above observation. Exports and imports of goods, as a share of the GDP, have occurred in sluggish phases since 1998, in which both categories can be seen to have very similar up-and-down movements. Under the NAFTA regime, the value of manufacturing exports grew to 106 billion dollars in 1998 and to 202 billion dollars in 2006, in spite of stagnating at about 140 billion dollars between 2001 and 2003. As a share of the GDP, exports by the same sector decreased by 3 percent in 2001 and 2002. 
Figure 2

Export and import of total goods as a share of GDP, and the GDP growth rate (annual rate)

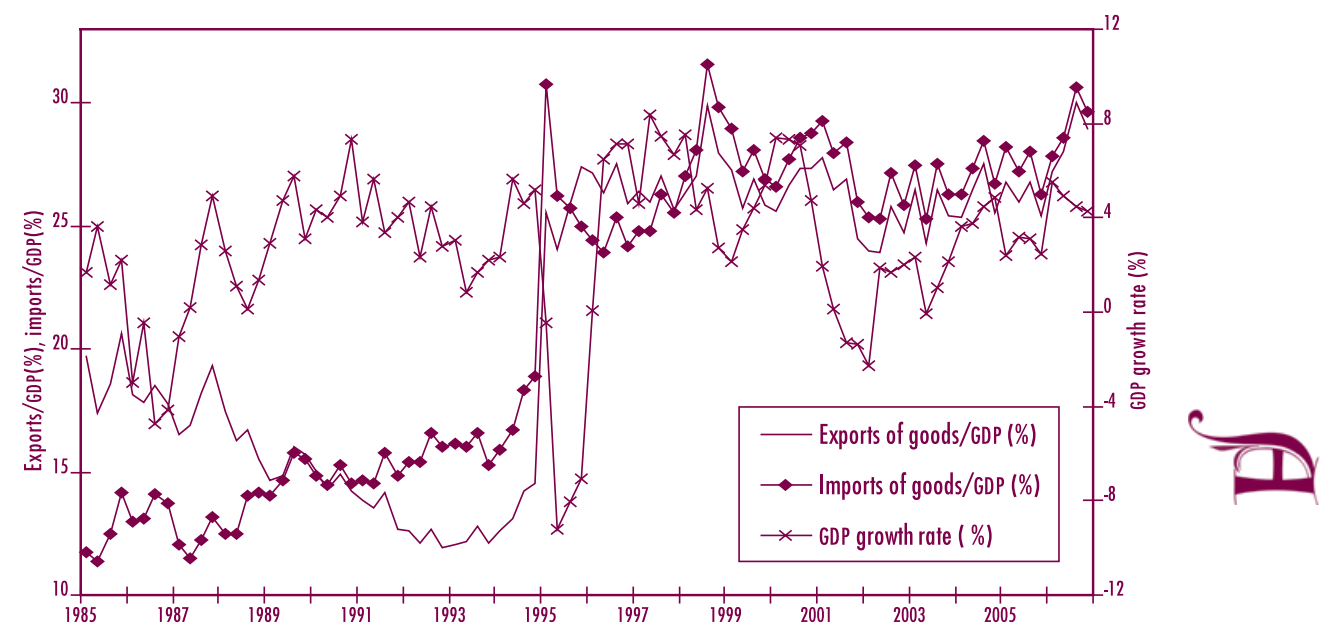

Source: Banco de México Indicadores económicos y financieros, http://www.banxico. org.mx/eInfo Financiera/FSinfoFinanciera.html

One of the main contributing factors to the stagnation of trade is the declining scale of the maquiladora industry. Total exports by the maquiladoras accounted for 53 billion dollars in 1998, and 79 billion dollars in 2000, but they fell to 77 billion dollars in 2003, and then rose to 112 billion dollars in 2006. At the same time, the manufacturing trade surplus by that industry increased from 10 million dollars in 1998 to 17 million dollars in 2000, and further to 23.6 million dollars in 2006. ${ }^{4}$ Meanwhile, the annual growth rate for fixed capital formation involving machines and equipment reached 24 percent in 1996 and 34.4 percent in 1997, which was then downsized to -6.2 percent in 2000 and -3.8 percent in 2001, before recovering somewhat to 12.8 in $2006 .{ }^{5}$ The growth of exports by the maquiladora has been structurally accompanied by an increase of imports in the same sector, vis-à-vis. Hence, the declining evolution of maquiladora trade since 2000, accompanied by a negative growth rate for fixed capital, may reflect a withdrawal from product lines by a large number of firms in the region.

4 INEGI, Banco de Información Estadística, Cobertura temática $>$ Sector externo $>$ Balanza comercial de la industria manufacturera, http://dgcnesyp.inegi.gob.mx/cgi-win/bdieintsi. exe /NIVJ100004\#ARBOL

5 INEGI, ibid., Cobertura temática>Indicadores económicos de coyuntura>Indicador de la inversión fija bruta, http://dgcnesyp.inegi.gob.mx/cgi-win/bdieintsi.exe/NIVA050009\# ARBOL 
$\langle\ldots \ldots \ldots \ldots \ldots \ldots \ldots \ldots$ 
Our analysis of the PROSEC leads us to propose a hypothesis. Large numbers of maquiladora firms have shifted their activities to temporary import for reexport, and therefore operate with a relatively reduced scale of manufacturing operations, negative fixed capital formation growth rates, and further decreased capital productivity. We shall elaborate on this hypothesis in the following sections.

\section{Models of Balance of payments-constrained growth}

\section{The balance of payments-constrained income growth model}

In the neoliberal economic context, export promotion policy is interpreted as a major way of fulfilling productivity and income growth, according to the neoclassical production function, with inputs of capital and labor such as $Y=f(K$, $L)$. Here, it is assumed that selections of the scale of inputs and of the composition of capital and labor are exogenous factors, which may be seen as being subject to aggregate demand. Hence, additional export demands realized by trade liberalization are seen as the leading determinants of both static and dynamic gains on the supply side.

The balance-of-payments-constrained growth model, introduced by A. P. Thirlwall, ${ }^{9}$ suggests that the economic growth rate in the long run is described as the ratio of "the growth rate of export amount/the income elasticity of import demand". The key notion is that factor inputs are determined endogenously, and that the availability of foreign exchange may be a fundamental constraint on the long-term rate of economic activity. Actually, although the world as a whole is not constrained by the balance of payments, there is good reason to suppose that semi industrialized countries are confronted by constraints from foreign exchange reserves and external debt. ${ }^{10}$ The balance-of-payments-constrained growth model, which takes into account capital flows, as described in Thirlwall and Hussain (2004), suggests that developing economies with trade surpluses and others with trade deficits face very different conditions. The model presented by Moreno-Brid (2004) is based on the following equations, with a constant ratio of the current account deficit to nominal income:

9 Thirlwall, 2002, pp.71.

10 Thirlwall and Hussain, 2004. 


$$
\begin{aligned}
& d x / x=\eta\left(d p / p-d p^{*} / p^{*}\right)+\pi(d w / w) \\
& d m / m=\varphi\left(d p^{*} / p^{*}-d p / p\right)+\xi(d y / y) \\
& \mu=p^{*} m /\left(p^{*} m-p x\right) \\
& O=\mu(d m / m)-(\mu-1) d x / x-\mu\left(d p / p-d p^{*} / p^{*}\right)-d y / y
\end{aligned}
$$

The first two equations indicate export and import demand functions with constant price elasticity, $x$ standing for real exports, $m$ for real imports, $p$ for domestic prices, $p *$ for foreign prices, $w$ for real incomes in the world market, and $y$ for real domestic incomes. In the model, $\eta(<0)$ is the price elasticity of exports, $\pi(>0)$ is the income elasticity of exports, and $\varphi(<0)$ and $\xi(>0)$ are the respective import elasticities. The nominal exchange rate is supposed to be fixed and equal to one. The price ratio $p / p^{*}$ displays the terms of trade. Equation (3) presents the definition of $\mu$ as a ratio of the amount of nominal imports to the current account deficit. Equation (4) indicates the equilibrium condition for the balance of payments, which is derived from the definition of the balance of payments: $B=\left(p^{*} m-p x\right) / p y=(M-X) / Y$. In this equation, $M$ and $X$ stand for values of imports and exports of goods, respectively, and $B$ represents the initial ratio of the current account deficit to domestic income, $Y$. Differentiating the equation for all the variables, we obtain the equilibrium condition for economic growth with a sustainable deficit:

$$
0=(M / Y) d m / m-(X / Y) d x / x-[(M-X) / Y] d y / y+(M / Y)(d p * / p *-d p / p)
$$

Substituting $M, X$ and $Y$ with $p m^{*}, p x$ and $p y$, and using equation (3), the equilibrium condition (4) is shown. The balance-of-payments-constrained growth rate for real domestic income is described as $y_{g}$, by solving equations (1)-(4):

$$
d y / y=y_{g}=\frac{(\mu-1) \pi(d w / w)+[\mu(\eta+\varphi+1)-\eta](d p / p-d p * / p *)}{\xi \mu-1}
$$

Multiplying (5) by $1 / \mu$, and defining $\theta$ as export/import ratio, we obtain the following:

$$
y_{g}=\frac{\theta \pi(d w / w)+(\theta \eta+\varphi+1)\left(d p / p-d p^{*} / p^{*}\right)}{\xi-(1-\theta)}
$$

Equation (6) suggests the following. The growth rate for income in the long term is identified as a function of the initial export/import ratio $(\theta)$, the price 
elasticity and income elasticity of exports $(\eta, \pi)$, the same for imports $(\varphi, \xi)$, the growth rate for income in the world market $w$, and the terms of trade $(p * / p)$.

We analyze two special cases, and we then refer to the normal case. Firstly, when the terms of trade are constant $(d p / p=d p * / p *)$, the balance-of-paymentsconstrained growth rate for income is defined as:

$$
y_{g}=\frac{\theta \pi(d w / w)}{\xi-(1-\theta)}=\frac{\theta(d x / x)}{\xi-(1-\theta)}
$$

Under the condition of $\xi-(1-\theta)>0$, growth rate $y_{g}$ for real income is positively related to the export growth rate, and negatively related to the income elasticity of imports $\xi$. Hence $\xi+\theta>1$ guarantees the theorem of balance-of-paymentsconstrained growth, referred to in this section. Moreover, in the economy with a trade surplus $(1<\theta)$, the export/import ratio may ease the restriction realized by the increased income elasticity for imports. Secondly, when the trade deficit converges towards equilibrium $(\theta=1)$, the growth rate, $y_{g}$, reduces to the following:

$$
y_{g}=\frac{\pi(d w / w)+(\theta \eta+\varphi+1)\left(d p / p-d p^{*} / p^{*}\right)}{\xi}
$$

In (8), the component $\theta \eta+\varphi+1$ with positive sign $(\theta \eta+\varphi+1>0)$ yields the result that an improvement in the terms of trade $(d p / p>d p * / p)$ is positively related to the balance-of- payments-constrained growth rate for income. In this case, $\theta \eta+\varphi+1$ corresponds to the Marshall-Lerner condition.

Thirdly, we elaborate determinant factors for the growth rate of $y_{g}$ under expanded trade deficits, and it is therefore necessary to identify the sign of $\xi-(\theta-1)$. From the definition of elasticity:

$$
\xi-(1-\theta)=\frac{d m / m}{d y / y}-\left[1-\left(p x / p^{*} m\right)\right]
$$

From (9), $\xi>(1-\theta)$ is achieved when:

$$
\frac{d m}{d y}>\frac{p^{*} m-p x}{p^{*} y}
$$

The implication of (10) is that the growth rate of the ratio of real imports to real income is greater than the existing ratio of the nominal trade deficit to nominal 
income, calculated using the foreign price. When $\xi>(1-\theta)$ is realized, the trade balance is in surplus, or the trade deficit converges towards equilibrium. In this case, the theorem for balance of payments-constrained growth is guaranteed by (6), which suggests that the growth rate for exports is positively related to the growth rate for real income. Nevertheless, from (10), the ratio of the trade surplus to nominal domestic income may decline, or the same trade deficit will increase over time. The share of the trade surplus in nominal income will be reduced, so the economy will be faced with a gap between its foreign exchange reserves and external debt burden. Here, the growth rate $y_{g}$ is positively related to external demand, although it will be restricted by a gap in the foreign exchange reserves. An improvement in the terms of trade may be one of the necessary conditions to ease this restrictive condition.

In the actual case of Mexico after 1998, $\theta$ has converged to one compared with the same category up to 1997. There is, therefore, good reason to suppose that the balance of payments-constrained growth rate of income $y_{g}$ is positively related to the growth of external demand and to an improvement in the terms of trade.

Meanwhile, $\xi<(1-\theta)$ is produced mainly because an increase in domestic income brings about a fall in the current account deficit as a proportion of income. In the case of $\xi<(1-\theta)$, the growth rate of $y_{g}$ is negatively related to exports and the improvement of the terms of trade. The result shows a limited possibility of a positive balance of payment-constrained growth in income, which is contradictory to the present situation. The implication is as follows. In the economy with a large and prolonged trade deficit, corresponding to the small size of $\theta$, income elasticity to import $\xi$ will be held at a high level to contain $\xi>(1-\theta)$. Therefore, to maintain a positive rate for balance of payments-constrained growth, given a significant scale for the trade deficit, some political direction is necessary to produce an increased income elasticity to import.

\section{The balance of payments-constrained capital productivity growth model}

Neoclassical economics considers that trade liberalization can encourage wholesale exports, allowing entities to produce more with increased total factor productivity. In this context, productivity is identified as a function of technological innovation. Thirlwall's Law conceptualizes growth as a demandled process, although Palley (2002) shows that both the supply-led and demand- 
led growth models neglect any discussion on how the growth rates of supply and demand are reconciled.

Domer's model recognizes that investment is a two-edged sword. It generates further increased demand through the investment multiplier, and induces expanded supply through additional fixed capital formation. In the balance of paymentsconstrained growth theory, a change in the scale of investment yields increases in demand, as follows: $d y_{d} / y_{d}=d k / k=i / k$, where $d k$ stand for a fixed investment flow. Increased supply produced by investment is described as: $d y_{s} / y_{s}=a i$, where $a$ represents capital productivity, or the output flow per unit of investment. ${ }^{11}$ In the above model, equations (1)-(4), $d y / y$ in (2) and (4) correspond to a determinant demand factor, and we therefore substitute $d y / y$ with $a i$. Thus (2) and (4) are described in the reformed equations as:

$$
\begin{gathered}
d m / m=\varphi\left(d p^{*} / p^{*}-d p / p\right)+\delta a i \\
(\mu-1) d x / x-\mu(d m / m)+\mu\left(d p / p-d p^{*} / p^{*}\right)=a i
\end{gathered}
$$

Equation (12) describes the capital productivity level as a function of the foreign exchange reserve gap and a change in the terms of trade. The balance of payments-constrained rate of capital productivity $a i_{g}$ is obtained by solving equations (1), (3), (11) and (12):

$$
a i_{g}=\frac{\theta \pi(d w / w)+(\theta \eta+\varphi+1)\left(d p / p-d p * / p^{*}\right)}{\delta-(1-\theta)}
$$

In equations (11) and the (13), $\delta$ stands for the import elasticity of investment demand. In most cases, the sign $\delta$ can be positive. Nevertheless, if a rigid import substitution industrialization policy is adopted for the investment goods sector, a huge shift of investment demand from imported goods to domestic goods may lead to $\delta<0$.

First, when the terms of trade are constant, using equation (13), balance of payments-constrained capital productivity is defined as:

$$
a i_{g}=\frac{\theta \pi(d w / w)}{\delta-(1-\theta)}=\frac{\theta(d x / x)}{\delta-(1-\theta)}
$$

11 Thirlwall, 2006, pp.132. 
With $\delta-(1-\theta)>0$, the completed investment $a i_{g}$ is positively related to the growth rate of exports and negatively related to the investment elasticity of imports $\delta$. We consider the case of $\delta>0$ and therefore the condition of $\delta+\theta>1$ to be guarantees that the capital productivity level is positively related to external demand, and negatively to elasticity $\delta$. Second, when the trade deficit converges to equilibrium, $a i_{g}$ can be reduced to the following:

$$
a i_{g}=\frac{\pi(d w / w)+(\theta \eta+\varphi+1)\left(d p / p-d p * / p^{*}\right)}{\delta}
$$

Here $\theta \eta+\varphi+1>0$ induces the result that an improvement in the terms of trade yields a further augmented level of capital productivity.

In the case of a prolonged trade deficit, the sign $\delta-(\theta-1)$ is identified as:

$$
\delta-(1-\theta)=\frac{d m / m}{d(a i) / a i}-\left[1-\left(p x / p^{*} m\right)\right]
$$

The necessary condition for $\delta>(1-\theta)$ is achieved, by the previously referred method using equations (9) and (10):

$$
\frac{d m}{d(a i)}>\frac{p^{*} m-p x}{p^{*} a i}
$$

A rough implication of (17) is as follows. When the ratio of the real import growth rate to the fixed investment growth rate exceeds the ratio of trade deficits to fixed capital, a positive sign for $\delta-(\theta-1)$ is induced.

The condition of $\delta>(1-\theta)$ can be realized in the condition of a prolonged trade surplus or a convergence of the trade deficit to equilibrium. Equation (13) indicates that balance of payments-constrained capital productivity $a i_{g}$ is positively related to the level of exports, and positively to an improvement in the terms of trade, as long as the Marshal-Lerner condition is completed. Meanwhile, $a i_{g}$ is negatively related to the investment elasticity of imports. Hence, from (17), the ratio of trade deficits to investment will rise, or the ratio of trade surpluses to investment falls. In either case, investment will be reduced, and the economy will be confronted with a foreign exchange reserve gap because of the trade deficit. Therefore, balance of payments-constrained productivity $a i_{g}$, positively related to external demand is restricted through a standstill in investment and the foreign exchange reserve burden. The suggestion is as follows. In the referred condition of a trade balance, in order to keep the growth of $a i_{g}$ at a significant 
rate, it is necessary to hold the investment elasticity of imports at an appropriate level and seek to improve the terms of trade.

In the case of $\delta<(1-\theta), a i_{g}$ is negatively related to the growth of external demand and to an improvement in the terms of trade. Therefore, in an economy with a large trade deficit (lower $\theta$ ) and/or with a reduced scale for $\delta$, an additional external demand yields negative influence to capital productivity $a i_{g}$. The implication is that, under a very large foreign exchange reserve gap and a foreign debt burden, additional export demand may not induce increased capital productivity, and that an expansion of fixed investment does not ease the trade deficit constraints.

It is convenient to summarize the analysis. $\xi_{>}(1-\theta)$ produces a greater possibility of a positive balance of payments-constrained income growth rate, under the conditions of a foreign exchange gap. On the other hand, $\delta>(1-\theta)$ yields a further possibility of positive capital productivity growth, $a i_{g}$, as long as the investment elasticity of imports and the terms of trade are controlled appropriately. The rates of $y_{g}$ and $a i_{g}$ are positively related to the income elasticity of exports and negatively to the same elasticity of imports.

\section{Empirical analysis of balance of payment-constrained growth in Mexico}

\section{Trade and income in the maquiladora}

industry and the non-maquiladora industry

The balance of payments-constrained growth model leads us to observe that the real income growth rate and the productivity of capital are functions of the income elasticity of imports and the foreign exchange gap. In this section, we present empirical models to calculate the income growth rate, $y_{g}$, and capital productivity, $a i_{g}$. Table 1 , between equations 1) to 5), shows the effects of the elasticity of imports on domestic income and the domestic price, and of the same for exports on U.S. income and the international price, for the whole manufacturing sector, the maquiladora industry and the non-maquiladora sector. Statistics for the maquiladora sector income are not available, so the models are based on the growth rates for total GDP in Mexico and the United States. The result of 6) and 7) in Table 1 shows the effects of the elasticity of imports on investment and domestic price, by those two sectors. 
TSUYOSHI YASUHARA

Table 1

Effects of the elasticity of imports and exports on domestic and U.S. income, and on investment by the maquiladora and non-maquiladora sectors

\begin{tabular}{|c|c|c|c|c|c|c|c|}
\hline \multirow{2}{*}{\multicolumn{2}{|c|}{$\begin{array}{l}\text { Effects of elasticity of imports } \\
\text { and exports on domestic } \\
\text { income and U.S. income }\end{array}$}} & \multicolumn{3}{|c|}{$\begin{array}{l}\text { 1983: } 1^{\text {st }} \text { quarter } \\
\text { 1997: } 4^{\text {th }} \text { quarter }\end{array}$} & \multicolumn{3}{|c|}{$\begin{array}{l}\text { 1998: } 3^{\text {rd }} \text { quarter } \\
\text { 2006: } 4^{\text {th }} \text { quarter }\end{array}$} \\
\hline & & coefficient & t value & $\begin{array}{c}\text { standard } \\
\text { error }\end{array}$ & coefficient & t value & $\begin{array}{l}\text { standard } \\
\text { error }\end{array}$ \\
\hline 1) Import = & $\xi$ & 3.56 & 6.6 & 0.54 & 3.77 & 16.2 & 0.23 \\
\hline$C+\xi(G D P)+\varphi(\text { price })^{*}$ & $\varphi$ & -0.16 & -0.5 & 0.3 & 0.05 & 0.5 & 0.12 \\
\hline 2) maquiladora imports= & $\xi$ & -0.85 & -1.6 & 0.5 & 3.86 & 10.2 & 0.37 \\
\hline$C+\xi(G D P)+\varphi$ (price) & $\varphi$ & 0.23 & 0.83 & 0.28 & 0.028 & 0.1 & 0.19 \\
\hline 3) non-maquiladora imports= & $\xi$ & 4.67 & 7.8 & 0.6 & 3.71 & 13.3 & 0.3 \\
\hline$C+\xi(G D P)+\varphi($ price $)$ & $\varphi$ & -0.17 & -0.5 & 0.32 & 0.07 & 0.5 & 0.15 \\
\hline 4) maquiladora exports= & $\pi$ & 4.69 & 5.7 & 0.81 & 7.18 & 11.1 & 0.64 \\
\hline$C+\pi($ US.GDP $)+\eta$ (price) & $\eta$ & 0.04 & 0.2 & 0.19 & 0.98 & 5.2 & 0.19 \\
\hline 5) non-maquiladora exports= & $\pi$ & -1.5 & -1.5 & 1.3 & 5.26 & 4.1 & 1.3 \\
\hline$C+\pi($ US.GDP $)+\eta$ (price) & $\eta$ & 0.16 & 0.5 & 0.3 & 0.35 & 0.9 & 0.37 \\
\hline 6) maquiladora imports = & $\delta$ & -0.16 & -1.2 & 0.13 & 1.48 & 9.7 & 0.15 \\
\hline$C+\delta$ (investment) $+\varphi$ (price) & $\varphi$ & 0.16 & 0.6 & 0.3 & 0.10 & 0.5 & 0.2 \\
\hline \multirow{2}{*}{$\begin{array}{l}\text { 7) non-maquiladora imports }= \\
C+\delta \text { (investment) }+\varphi \text { (price) }\end{array}$} & $\delta$ & 1.31 & 11.1 & 0.12 & 1.42 & 12.0 & 0.12 \\
\hline & $\varphi$ & 0.04 & 0.2 & 0.25 & 0.14 & 0.9 & 0.16 \\
\hline
\end{tabular}

All results estimated using the Ordinary Least Squares method with quarterly statistics.

* "Prices" corresponds to the terms of trade published as the real exchange rate index (peso price/dollar price), calculated by the consumer price index in Mexico and another 111 countries. Source: Banco de México Estadísticas, http://www.banxico.org.mx/tipo/estadisticas/index.html. Bureau of Economic Analysis, National Economic Accounts. Percentage change from preceding period, http://www.bea.gov/national/index.htm\#gdp.

The estimated values of the elasticity of import and the export/ import ratio help us to see that in each model the condition of $\xi-(1-\theta)>0$ and $\delta-(1-\theta)>0$ is fulfilled. The income elasticity of maquiladora imports has increased from -0.85 to 3.86. During 1998-2006, this sector had the highest income elasticity of imports and the effect of the further elevated elasticity of exports on U.S. income at 7.18, compared with the same category during 1983-1997. The rate of $y_{g}$ for the maquiladoras is estimated as -40.95 in 1983-1997, and as 7.04 in 1998-2006.

With the results shown in Table 1 we estimate the balance of paymentsconstrained growth rate for income and balance of payments-constrained capital productivity in both sectors (see Table 2). The period between 1983 and 1997 was characterized by the adjustment phase in the trade balance after the devaluations. The balance of payments-constrained growth rate for income in the two sectors is estimated with negative signs, inconsistent with the actual statistic of 15.66 during 1990-1997. The result suggests that the crisis influenced so highly as to give a negative rate for the balance of payments-constrained growth rate. In the 
adjustment phase after the crisis, maquiladora exports were limited by demand in the U.S. economy, while most products produced by the non-maquiladora were produced for the domestic market.

Table 2

Estimated balance of payments-constrained income growth rate, and balance of payments-constrained capital productivity for the maquiladora and the non-maquiladora sectors

\begin{tabular}{|c|c|c|}
\hline Balance of payments-constrained rate for: & $\begin{array}{l}\text { 1983: } 1^{\text {st }} \text { quarter } \\
\text { 1997: } 4^{\text {th }} \text { quarter }\end{array}$ & $\begin{array}{l}\text { 1998: } 3^{\text {rd }} \text { quarter } \\
\text { 2006: } 4^{\text {th }} \text { quarter }\end{array}$ \\
\hline 1) maquiladora income & -40.95 & 7.04 \\
\hline 2) maquiladoras capital productivity & 134.6 & 16.6 \\
\hline$\theta$ (export/import ratio) for maquiladoras & 1.31 & 1.28 \\
\hline 3) non-maquiladora income & -0.64 & 3.8 \\
\hline 4) non-maquiladora capital productivity & 16.54 & 11.08 \\
\hline$\theta$ (export/import ratio) for non-maquiladora & 1.04 & 0.78 \\
\hline Actual GDP growth rate & 2.09 & 3.2 \\
\hline Actual growth rate of maquiladora producers & $15.66(1990-1997)$ & $9.4(1997-2004)$ \\
\hline Actual growth rate of fixed capital formation & 8.09 & 6.6 \\
\hline
\end{tabular}

Source: Calculation by author, based on the following:

Banco de México, Estadísticas, http://www.banxico.org.mx/tipo/estadisticas/ index. html. Instituto Nacional de Estadística Geografía e Informática (INEGI), Banco información económica, http://www.inegi.gob.mx/est/default.asp?c=119.

Bureau of Economic Analysis, National Economic Accounts. Percentage change from preceding period, http://www.bea.gov/national/index.htm\#gdp.

In Table 2, rows 1) and 3) show the balance of payments-constrained growth rates of income for the maquiladoras and the non-maquiladoras, these being evaluated as 7.04 and 3.8, respectively, between 1998 and 2006. The period is distinguished by a stand-still in growth for trade deficits as a share of GDP, and sluggish exports and imports. The estimated result of the balance of payments-constrained growth rate for income indicates that the national economy has been highly influenced by the U.S. economy in the adjustment phase, but to quite different degrees for the two sectors. In particular, since 2000, policies to promote temporary import for re-export, such as PROSEC, have induced higher income elasticity for maquiladora imports in the electrical appliances and electronic equipment sectors.

The income elasticity to import by the non-maquiladora industry declined from 4.67 during 1983-1997 to 3.71 during 1998-2006, while the same elasticity 
for the maquiladoras increased from -0.85 to 3.86 (Table 1 ). The quite different changing patterns of the income elasticity to import suggest that the maquiladora and non-maquiladora sectors have not constructed forward and backward linkages in their investment demands. Imports by the maquiladora industry are composed exclusively of intermediate goods during the period under study. Meanwhile, among the goods imported by the non-maquiladora industry, intermediate goods occupy 61 percent in 1994 and 2006, and 67.8 percent in 1997.

Earlier studies assessing the synchronization of the business cycle between the United States, Canada and Mexico after NAFTA estimate the sensitivity coefficients of Mexico's GDP growth rate with respect to the United States and other countries. ${ }^{12}$ Our analysis presents an alternative interpretation of business cycle synchronization. The growth of maquiladora and non-maquiladora export elasticity to U.S. income corresponds to the enormous influence of the U.S. economy on Mexico. On the other hand, the two sectors have had relatively close levels of income elasticity to import since 1998. These circumstances have further deepened the connection of import demand between Mexico and the North American countries, to a similar extent in the maquiladora and non-maquiladora industries.

Balance of payments-constrained capital productivity for the maquiladoras fell from 134.6 during 1983-1997 to 16.6 during 1998-2006 (as shown in Table 2). The result is compatible with the current growth rate statistics for maquiladora production, which are 15.66 and 9.4 for the same periods. The growth rate for fixed capital formation also fell from 8.09 in 1983-1997 to 6.6 in 1998-2006.

During the period 1983-1997, balance of payments-constrained capital productivity for the maquiladoras at 134.6 greatly exceeds the same for the nonmaquiladoras (16.54). However, in 1998-2006, this rate for the maquiladoras and non-maquiladoras is estimated to have been relatively close, at 16.6 and 11.08 , respectively. The result shown in Table 2 points to a great difference between the two sectors. Balance of payments-constrained capital productivity for the maquiladoras falls dramatically from 134.6 in 1983-1997 to 16.6 in 1998-2003, while, the same productivity for the non-maquiladoras declined only slightly, from 16.54 to 11.08 for the same two periods. The observation is consistent with a lack of forward and backward linkage for product lines between two sectors.

12 Lederman, Maloney and Servén, 2005, pp.85-111. 
Until the decade of the 1990s, the scale of fixed capital for the maquiladora industry was larger than that of the non-maquiladora firms. Recently, activity for a large part of the maquiladora industry has declined. On the other hand, some non-maquiladora firms have added more productive equipment, possibly exceeding that of the maquiladoras. Our revised result for balance of paymentsconstrained capital productivity for the two sectors offers an interpretation of this fact from the demand side. During the period referred to, a positive sign is identified for $\xi-(1-\theta)$, and therefore the wholesale economy has been confronted with a foreign exchange gap. Particularly in the phase of the standstill in trade deficits, firms in both sectors have tended to make full use of foreign exchange earned from exports. Hence, operations by the maquiladora industry and the nonmaquiladoras have been conditioned by the foreign exchange gap, which has led to closely estimated levels for the import elasticity of fixed capital and balance of payments-constrained capital productivity.

\section{Conclusion}

The balance of payments-constrained growth rate for income was estimated with significant statistics between 1998 and 2006 for the maquiladora and nonmaquiladora sectors. The estimated results for balance of payments-constrained capital productivity suggest that investment by maquiladoras and nonmaquiladoras faced the common condition of a foreign exchange gap, during the phase of a stagnant trade deficit.

What stand out are, firstly, the changing patterns of the income elasticity to import and export for the maquiladora and non-maquiladora sectors, and, secondly, the relatively close levels of balance of payments-constrained capital productivity for the two sectors since 1998. The two manufacturing sectors have not built forward and backward linkages for their product lines, even though they have been conditioned by similar trade deficits and foreign exchange gaps. Furthermore, both the maquiladoras and non-maquiladoras are interconnected with the U.S. economy via a high income elasticity to export. The observed result has been stimulated by trade liberalization, particularly by the promotion policy of temporary imports for re-export, such as the PROSEC since 2000.

In the context of supply-side economics, to ensure export-led growth, it is necessary to establish policies that transform the manufacturing sector's components and/or introduce new industries with comparative advantages. PROSEC has not achieved a structural change in comparative advantage. The 
TSUYOSHI YASUHARA

\section{6}

alternative approach using the balance of payments-constrained growth model suggests the importance of a demand-side viewpoint to interpret export-led growth policy. To achieve a higher growth rate for income and greater capital productivity, it is necessary to manage the trade balance and the foreign exchange reserves. Currently, the effects of the terms of trade and import elasticity on domestic income should be managed adequately.

\section{References}

Dussel Peters, Enrique and Jorge Katz, "Diferentes estrategias en el nuevo modelo económico latinoamericano: importaciones temporales para su reexportación y transformación de materias primas", http:// dusselpeters.com/13.pdf, 2002.

Lederman, Daniel, William F. Maloney and Luis Servén, Lessons from NAFTA for Latin America and the Caribbean, Stanford, The World Bank/Stanford University Press, Washington D.C., 2005.

Moreno-Brid, Juan Carlos, "Balance of payments constrained growth: the case of Mexico", in McCombie, J. S. L. and A. P. Thirlwall (eds.), 2004.

Moreno-Brid, Juan Carlos, Jesús Santamaría, and Juan C. Rivas Valdivia, "Manufactura y TLCAN: un camino de luces y sombra," Economía UNAM, Vol.3, No.8., 2006.

McCombie, J. S. L. and A. P. Thirlwall (eds.) Essays on Balance of Payments Constrained Growth: Theory and Evidence, Routledge, London and New York, 2004.

Palley, Thomas I., "Pitfalls in the theory of growth: an application to the balance of payments-constrained growth model," in Setterfield, Mark (ed.) The Economics of Demend-led Growth, Challenging the Supply-side Vision of the Long Run, Edward Elgar, Cheltenham, and Northampton, MA, 2002.
Pieper, Ute, "Openness and structural dynamics of productivity and employment in developing countries: a case of de-industrialization?" Employment and Training Papers 14, International Labour Office, Geneva, 1998.

Secretaría de Economía, Cuarto informe de labores, México D.F., http://www. economia.gob.mx/pics/p/p1376/Cuarto InformedeLabores.pdf, 2004.

Shafaeddin, S. M., "Trade liberalization and economic reform in developing countries: structural change or de-industrialization?", Discussion Papers No.179, United Nations Conference on Trade and Development (UNCTAD), Geneva, 2005.

Thirlwall, A. P., The Nature of Economic Growth, an Alternative Framework for Understanding the Performance of Nations, Edward Elgar Publishing Limited, Cheltenham, Edward Elgar Publishing Inc., Massachusetts, 2001.

_, Growth and Development with Special Reference to Developing Economies, eighth edition, Palgrave Macmillan, New York, 2006.

Thirlwall, A. P. and M. Nureldin Hussain, "The balance of payments constraint, capital flows and growth rate differences between developing countries," in McCombie, J. S. L. and A. P. Thirlwall (eds.), 2004. 